University of New Hampshire

University of New Hampshire Scholars' Repository

\title{
"Above all Greek, above all Roman Fame": Classical Rhetoric in America during the Colonial and Early National Periods
}

James M. Farrell

University of New Hampshire, jmf@unh.edu

Follow this and additional works at: https://scholars.unh.edu/comm_facpub

Part of the Classical Literature and Philology Commons, Cultural History Commons, Liberal Studies Commons, Rhetoric Commons, and the United States History Commons

\section{Recommended Citation}

James M. Farrell, "'Above all Greek, above all Roman fame': Classical Rhetoric in America during the Colonial and Early National Periods," International Journal of the Classical Tradition 18:3, 415-436.

This Article is brought to you for free and open access by the Communication at University of New Hampshire Scholars' Repository. It has been accepted for inclusion in Communication Scholarship by an authorized administrator of University of New Hampshire Scholars' Repository. For more information, please contact Scholarly.Communication@unh.edu. 


\title{
"Above all Greek, above all Roman Fame": Classical Rhetoric in America during the Colonial and Early National Periods
}

\author{
James M. Farrell \\ University of New Hampshire
}

The broad and profound influence of classical rhetoric in early America can be observed in both the academic study of that ancient discipline, and in the practical approaches to persuasion adopted by orators and writers in the colonial period, and during the early republic. Classical theoretical treatises on rhetoric enjoyed wide authority both in college curricula and in popular treatments of the art. Classical orators were imitated as models of republican virtue and oratorical style. Indeed, virtually every dimension of the political life of early America bears the imprint of a classical conception of public discourse. This essay marks the various specific aspects of the reception and influence of the classical rhetorical tradition in the learning, speaking and writing of Americans in the eighteenth and early nineteenth centuries.

\section{Introduction}

In his biography of Patrick Henry, William Wirt compared the Virginian statesman to the great orators of the classical period. "Middleton, in his life of Cicero," wrote Wirt, "tells us that the first great speech of that orator, his defence of Roscius of Amerino, was made at the age of twenty-seven; the same age, he adds, at which the learned have remarked, that Demosthenes distinguished himself in the assembly of the Athenians." It was also at the age of twenty-seven, Wirt revealed, that the oratorical talent of Patrick Henry "first became known to himself and to the world." It was not unusual for early American historians to draw analogies between the most talented American orators and the brilliant speakers of the classical age. That an orator such as Patrick Henry should be compared to Demosthenes and Cicero was to be expected when, for generations, educated Americans had looked to Athens and Rome for instruction in the ancient art of rhetoric, and for models of the most eloquent rhetorical expression.

\footnotetext{
${ }^{1}$ William Wirt, Sketches of the Life and Character of Patrick Henry, $3^{\text {rd }}$ edition (Philadelphia: James Webster, 1818), 36. See Conyers Middleton, The History of the Life of M. Tullius Cicero, Vol. 1 (Basil: J. J. Tourneisen and J. L. Legrand, 1790), 37. Middleton's work was widely read in eighteenth- and early nineteenth-century America.
} 
The influence of classical rhetoric and oratory in early American culture can be traced along several distinct paths. First, until the early nineteenth century, the rhetorical curriculum in American colleges was strictly classical. Students read the best works on rhetoric from Greece and Rome and studied the oratory of Demosthenes and Cicero. Moreover, instruction in rhetoric followed classical doctrine as professors of rhetoric relied largely upon works by Cicero, Quintilian, Aristotle and Longinus to inform their lectures. Second, the most influential modern treatises on rhetoric available in the United States also relied heavily on classical rhetorical theory and classical oratorical examples. Third, most writers treating rhetoric and oratory in the literary periodicals of the colonial and early national periods viewed their subject as firmly rooted in the classical tradition. Fourth, many American orators and writers saw themselves and their rhetorical situations in classical terms. Often these advocates selected classical pseudonyms, relied on classical allusions and analogies, and were remembered by eulogists and biographers (such as William Wirt) as akin to classical heroes.

Classical rhetoric and oratory, therefore, were readily received into American culture of the colonial and early national periods, a reception that can be explained, in part, by the perceived relationship between the virtue of eloquence and the national commitment to political freedom. Classical rhetorical theory and practice were grounded on the assumption that eloquent public speech was a practical necessity in a free society. Such doctrines and models appealed to a political community built upon the assertion of national independence and personal liberty. "The only birth place of eloquence," John 
Quincy Adams wrote, "must be a free state," for "eloquence is the child of liberty.",

"When did Greece or Rome present a fairer field for eloquence, than that which now invites the culture of the enlightened citizens of Columbia?" asked a graduating Harvard student in 1794. He wished that America would always "afford more than one Demosthenes, to support the sacred cause of freedom," and that "more than Ciceronian eloquence be ever ready to plead for injured innocence and suffering virtue." Under the blessing of liberty, the student told his audience, American eloquence would rise "above all Greek, above all Roman fame.”3 A graduating senior at Burlington College (Vermont) agreed. Gardner Child told the Phi Sigma Nu Society in 1806 that in "this land of virtuous liberty" the "advantages for the improvement of Eloquence are numerous and great." He too hoped that America would be "blessed with a Demosthenes, Cicero, or Pitt" to inspire Americans in their moments of national peril and confusion. ${ }^{4}$

\section{Classical Theory in America}

As a virtuous democratic art, rhetoric was nurtured in the academies and colleges of the new republic. Instruction was almost exclusively classical. "A subject, which has exhausted the genius of Aristotle, Cicero, and Quintilian, can neither require nor admit much additional illustration," Adams announced in his 1806 Inaugural Oration as Boylston Professor of Rhetoric and Oratory at Harvard. ${ }^{5}$ Indeed, in offering a brief

\footnotetext{
${ }^{2}$ John Quincy Adams, Lectures on Rhetoric and Oratory, 2 vols. (Cambridge: Hilliard and Metcalf, 1810; rpt. New York: Russell \& Russell, 1962), 1:68. See also John Lawson, Lectures Concerning Oratory (Dublin: George Faulkern, 1759; rpt. Carbondale: Southern Illinois University Press, 1972), 24-30.

${ }^{3}$ Joseph Perkins, “An Oration on Eloquence," Massachusetts Magazine (July 1794): 423-429. Reprinted in Caleb Bingham, ed., Columbian Orator (Boston: Manning and Loring, 1797), 30-34.

${ }^{4}$ Gardner Child, "An Oration on Eloquence" (Burlington: Greenleaf \& Mills, 1806), 17, 19.

${ }^{5}$ J. Q. Adams, Lectures (above, n. 2), 1:28. On the further influences of classical rhetoric on the public life of John Quincy Adams see Lyon Rathbun, "The Ciceronian Rhetoric of John Quincy Adams," Rhetorica 18 (2000): 175-215. Caroline Winterer referred to Adams, who died in 1848, as "last in the line of
} 
outline of classical rhetoric, it is not necessary to go much beyond the presentation of those doctrines in Adams's lectures to Harvard students, since he understood his mission to be no more than to offer "a system of rhetoric and oratory, founded upon the classical theories of antiquity."

Based on their observations of the civic business in their own societies, classical rhetoricians divided the art into "three classes of orations, the demonstrative, the deliberative, and the judicial." ${ }^{7}$ These three genres also informed the theory and practice of rhetoric in early America. Ambitious young men seeking the glory of oratorical fame strove to achieve excellence in each of the classical genres. For example, part of what made Daniel Webster the greatest American orator, said Rufus Choate in his remarks upon the death of the eloquent hero, was "the remarkable phenomenon of excellence in three unkindred, one might have thought, incompatible forms of public speech, - that of the forum, with its double audience of bench and jury, of the halls of legislation, and of the most thronged and tumultuous assemblies of the people."

The first genre, forensic oratory, treated matters of justice and injustice in speeches of accusation or defense. The goal of legal discourse, John Quincy Adams wrote, was to manage "the litigation of causes public or private, civil or criminal, in the

classically-educated gentlemen-statesmen," and "a great admirer of the classics and the republican virtues with which they could instruct modern Americans." See Winterer, "Classical Oratory and Fears of Demagoguery in Antebellum America," in Michael Meckler, ed., Classical Antiquity and the Politics of America: From George Washington to George W. Bush (Waco: Baylor University Press, 2006), 42.

${ }^{6}$ J. Q. Adams, Lectures (above, n. 2), 2:140-41.

${ }^{7}$ J. Q. Adams, Lectures (above, n. 2), 1:229. Aristotle affirms that "there are three divisions of oratory-(1) political, (2) forensic, and (3) the ceremonial oratory of display." See Rhetoric, trans. W. Rhys Roberts (New York: Modern Library, 1954), 1358b. See also Cicero, De Inventione I.ix.12, and Quintilian, Institutio Oratoria III.iv.12-15.

${ }^{8}$ Rufus Choate, "Remarks Before the Circuit Court on the Death of Mr. Webster," in Addresses and Orations of Rufus Choate, $7^{\text {th }}$ edition (Boston: Little Brown, 1897), 233. See also Robert Ferguson, Law and Letters in American Culture (Cambridge: Harvard University Press, 1984), 208-209. 
courts of justice." ${ }^{9}$ Until the mid-nineteenth century, American forensic oratory was formed almost exclusively upon classical rhetorical principles, and lawyers often sought to emulate the legal eloquence of the classical age - especially the legal oratory of Demosthenes and Cicero. To John Adams (father of the Harvard professor) legal oratory was "an unlimited Field. A Field in which Demosthenes, Cicero and others of immortal Fame have exulted before me!"10 Indeed, many American orators succeeded in achieving oratorical fame by distinguishing themselves in the forensic area. During his argument against Writs of Assistance, James Otis was "a flame of fire." He "hurried away every thing before him" with " a promptitude of classical allusions, a depth of research, a rapid summary of historical events and dates, a profusion of legal authorities, a prophetic glance of his eyes into futurity, and a rapid torrent of impetuous eloquence."11 "No harangue of Demosthenes or Cicero," John Adams believed, "ever had such effects upon this globe as that speech."12 Those who heard Patrick Henry's debut as a forensic pleader in the "Parson's Cause," recalled how he "made their blood run cold, and their hair to rise on end" as he "completely bewildered" the jury with his oratory. The oration earned Henry popular fame and the title "the orator of nature."13 Daniel Webster, too, achieved renown for his legal speaking as much as for his efforts in other genres. He was praised for "the clearness and absorbing power of his argument" in the Dartmouth College case. "When I see my Alma Mater," said Webster in his peroration, "surrounded, like Caesar in the senate-house, by those who are reiterating stab upon stab, I would not, for this right

\footnotetext{
${ }^{9}$ J. Q. Adams, Lectures (above, n. 2), 1:278-79.

${ }^{10}$ John Adams, The Earliest Diary of John Adams, ed. L. H. Butterfield (Cambridge: Belknap Press of the Harvard University Press, 1966), 65.

${ }^{11}$ John Adams to William Tudor, 29 March 1817, in The Works of John Adams, 10 Vols., ed. Charles Francis Adams (Boston: Little Brown, 1856), 10:247.

${ }^{12}$ John Adams to William Tudor, 18 December 1816, The Works of John Adams 10:233.

${ }^{13}$ Wirt, Sketches of the Life and Character of Patrick Henry (above, n. 1), 26-27, 32.
} 
hand, have her turn to me, and say, Et tu quoque, mi fili! And thou too, my son!" 14 His

forensic reputation grew with his oration in the Knapp-White murder trial, "a more difficult and higher effort of mind," thought Rufus Choate, "than that more famous 'Oration for the Crown'.,'15

Deliberative oratory, or the eloquence of the political assembly, is concerned with the honor and expedience of public policy, including "all the subjects of legislation, of taxation, of public debt, public credit, and public revenue; of the management of public property; of commerce; treaties and alliances; peace and war."16 It should not be surprising that some speakers tried to imitate the political oratory of Greece or Rome in a land whose deliberative institutions are formed on the models of the Athenian assembly and Roman senate. ${ }^{17}$ In the Continental Congress men like John Adams, with "Roman firmness," addressed fellow delegates "in that more than Roman Senate," arguing for passage of the Declaration of Independence. ${ }^{18}$ Adams believed his oration for

\footnotetext{
${ }^{14}$ Rufus Choate, "A Discourse Commemorative of Daniel Webster," in Addresses and Orations of Rufus Choate (above, n. 8), 275-76.

${ }^{15}$ Choate, "A Discourse Commemorative of Daniel Webster," in Addresses and Orations of Rufus Choate (above, n. 8), 267. We can recognize the classical influence on Webster by examining the structure of his prosecution argument in that sensational case. Webster's address corresponds almost exactly to the arrangement for a forensic discourse recommended by Cicero in De Inventione and by the author of Rhetorica Ad Herennium. For example, after offering a detailed account of the facts in the case, he turns to his partition and identifies the question, or point of controversy, for the jury: "Your first inquiry, on the evidence, will be, was Captain White murdered in pursuance of a conspiracy, and was the defendant one of this conspiracy? If so, the second inquiry is, was he so connected with the murder itself as that he is liable to be convicted as a principal?" The classical form is still in force as Webster marks the transition from his proof to his peroration: "Gentlemen, I have gone through with the evidence in this case, and have endeavored to state it plainly and fairly before you. I think there are conclusions to be drawn from it, which you cannot doubt" (Daniel Webster, "The Salem Murder Trial, August 1830," in The Papers of Daniel Webster: Speeches and Formal Writings, Volume 1, 1800-1830 [Hanover, NH: University Press of New England, 1986], 406, 444).

${ }^{16}$ J. Q. Adams, Lectures (above, n. 2), 1:259. See Aristotle, 1359b, and Quintilian III.viii.14.

${ }^{17}$ See John E. Rexine, "Classical Political Theory and the United States Constitution," Greek Orthodox Theological Review 21 (1976): 321-340; Gilbert Chinard, "Polybius and the American Constitution," Journal of the History of Ideas 1 (1940): 38-58; R. A. Ames and H. C. Montgomery, "the Influence of Rome on the American Constitution," Classical Journal 30 (1934-35): 19-27.

${ }^{18}$ William F. Thornton, "Eulogy, pronounced at Alexandria, District of Columbia, August 10, 1826," in A Selection of Eulogies, Pronounced in the Several States in Honor of Those Illustrious Patriots and
} 
Independence, now lost, addressed a question "of more importance to his country and to the World" than any that challenged "the ancient Orators of Greece and Rome."19 In that same Congress, Patrick Henry enlarged his fame and Richard Henry Lee earned a reputation as the "Cicero of America." ${ }^{20}$ During the early republic other orators stepped forward to form the organic plan and set the inaugural course of the nation with their eloquence. Public men such as Fisher Ames, James Madison, John Randolph, John Quincy Adams, Henry Clay, John C. Calhoun, and of course Daniel Webster captured the attention of the nation with the penetrating force of their deliberative eloquence. In debates which rivaled the oratorical drama of ancient times, the great American orators decided vital questions of national policy and helped form the national character. These men could often shed light on a contemporary issue by drawing a proper and useful parallel from ancient times. Speaking at the constitutional convention in Philadelphia in 1787, for example, Alexander Hamilton revealed his classical training on two levels. First he employed ancient history as a support for his political position. Explaining the defects of a confederacy between sovereign states, Hamilton argued that in power and influence the states "will generally be an overmatch of the Gen[eral] Gov[ernment] and render any confederacy, in its very nature precarious." His theory, he continued, was "proved by experience:"

The Amphyctionic [sic] Council had it would seem ample powers for general purposes. It had in particular the power of fining and using force ag[ainst] delinquent members. What was the consequence? Their decrees were mere signals of war. The Phocian war is a striking example of it. Philip at length taking

Statesmen, John Adams and Thomas Jefferson (Hartford: Robinson \& Co. and Norton \& Russell, 1826), 336; Samuel Smith, "Eulogy Pronounced at Baltimore," in A Selection of Eulogies, 79.

${ }^{19}$ John Adams, Diary and Autobiography of John Adams, 4 vols., ed. L.H. Butterfield (New York: Atheneum, 1966), 3:396-97.

${ }^{20}$ See Wirt, Sketches of the Life and Character of Patrick Henry (above, n. 1), 107. 
advantage of their disunion, and insinuating himself into their Councils, made himself master of their fortunes.

Yet, more subtly, Hamilton also reminded his listeners of the great Athenian opponent of Philip as he began his remarks echoing the exordium of Demosthenes' First Philippic. Hamilton "had been hitherto silent on the business before the Convention, partly from respect to others whose superior abilities age $\&$ experience rendered him unwilling to bring forward ideas dissimilar to theirs." Yet now, the country faced with a crisis "too serious to permit any scruples whatever to prevail over the duty imposed on every man to contribute his efforts for the public safety \& happiness.",21

Many less eloquent American orators, however, overstepped the bounds of decorum in the use of classical allusion. Some speakers addressed even minor deliberative issues "by ascending to the dawn of history, and then flounder[ing] down through the ages, to the bill or resolution under discussion, followed helter-skelter by nearly every conqueror and sage of antiquity." 22 Indeed, it was the tedious borrowing of "second-hand, threadbare classical ornaments" and "undigested bits of classical lore out of Plutarch" by speakers "in the completest ignorance of even the outside of antiquity" which hastened the decline of classical rhetoric and oratory in America, and led one

\footnotetext{
${ }^{21}$ Gaillard Hunt and James Brown Scott, eds., The Debates in the Federal Convention of 1787 Which Framed the Constitution of the United States of America, reported by James Madison (New York: Oxford, 1920), 111-113. Demosthenes began his First Philippic: "Had we been convened, Athenians, on some new subject of debate, I had waited until most of the usual persons had declared their opinions. If I had approved of any thing proposed by them, I should have continued silent: if not, I had then attempted to speak my sentiments. But since those very points on which these speakers have oftentimes been heard already are, at this time to be considered, though I have risen first, I presume I may expect your pardon; for if they on former occasions had advised the necessary measures, ye would not have found it needful to consult at present." Thomas Leland, trans., All the Orations of Demosthenes, pronounced to Excite the Athenians Against Philip King of Macedon, $2^{\text {nd }}$ edition (London: W. Johnston, 1757), 1-2.

22 "The Gift of Gab," Nation 3 (26 July 1866): 75, cited in Barnet Baskerville, "Some American Critics of Public Address, 1850-1900," Speech Monographs 17 (1950): 8.
} 
sarcastic critic to propose a Congressional rule forbidding members to refer to any man, institution, or event prior to 1640 A.D. ${ }^{23}$

Epideictic or demonstrative oratory, the eloquence of the public ceremony, "was that species of public speaking which consists of discourse, formally prepared, and delivered in celebration of some person or public event." ${ }^{24}$ Demonstrative orations aimed to mark special occasions, reaffirming public values in speeches of praise or blame, establishing and committing to the collective memory the fame or infamy of public characters. The rise of demonstrative eloquence was one "distinguishing feature" of American culture, John Quincy Adams thought. In the numerous Independence Day orations and the "many other occasions public and private" when we "hear orations," he saw evidence that Americans had resumed "that particular style of speaking, which was so customary among the Greeks and Romans, but which in the island of Great Britain seems to be almost entirely unpractised." Such orations, he believed, contributed to the national character by "stimulating genius, patriotism, and beneficence," and by "teaching useful lessons of national virtue."25

Among the greatest of America's ceremonial orators was one of Adams's students, Edward Everett, later “America’s first systematically trained classical scholar." Named “our Cicero” by Ralph Waldo Emerson, Everett's oratorical career ranged from remarks at local cattle shows to the principal oration at the dedication of the Gettysburg National Cemetery. ${ }^{26}$ His most famous demonstrative address, "the Character of

\footnotetext{
23 "Eloquence of the Impeachment Trial," Nation 6 (7 May 1868): 367, cited in Baskerville, "Some American Critics," 8.

${ }^{24}$ J. Q. Adams, Lectures (above, n. 2), 1:277. See Aristotle, 1366a-1368a, and Quintilian III.vii.1-28.

${ }^{25}$ J. Q. Adams, Lectures (above, n. 2), 1:179-180.

${ }^{26}$ Meyer Reinhold, Classica Americana: The Greek and Roman Heritage in the United States (Detroit: Wayne State University Press, 1984), 204; Ralph Waldo Emerson, Journals of Ralph Waldo Emerson:
} 
Washington," he delivered 137 times between 1856 and 1859, during a national speaking tour to raise money for the Ladies Mount Vernon Association. ${ }^{27}$ Everett, like other orators of the age, was fond of comparing ancient times with the events or people he remembered in his epideictic oratory. Commemorating the "first Battles of the Revolution," Everett asked his audience if they must go "back to find in obscure texts of Greek and Latin the great exemplars of patriotic virtue?" He believed such models could be found "nearer home, in our own country, on our own soil . . in the native eloquence of our mother tongue." The American colonial and provincial legislatures, he believed, "exhibit to us models of the spirit and character which gave Greece and Rome their name and their praise among the nations. ${ }^{, 28}$ Indeed, Everett himself, as a master of demonstrative oratory, embodied the best of American virtue and "native eloquence." In addition to the division of oratory into three types, classical rhetoricians divided the art of rhetoric into various offices or faculties. As Adams explained to his students, the "five constituent parts of rhetoric," are "invention, disposition, elocution, memory, and pronunciation, or action." ${ }^{29}$ Invention was the discovery of material and arguments to be used in a particular discourse. It was, said Adams, "the most powerful test, both of the speaker's genius and of his learning." 30 Such discovery was accomplished by analysis of the specific rhetorical situation - the "observing in any given

1820-1872, eds. Edward Waldo Emerson and Waldo Emerson Forbes, volume 1 (Boston: Houghton Mifflin, 1909), 207.

${ }^{27}$ See Ronald F. Reid, ed., Three Centuries of American Rhetorical Discourse: An Anthology and a Review (Prospect Heights, Illinois: Waveland, 1988), 426-428.

${ }^{28}$ Edward Everett, "The First Battles of the Revolutionary War," [1825] in Orations and Speeches on Various Occasions, vol. 1 (Boston: Little and Brown, 1850), 77.

${ }^{29}$ J. Q. Adams, Lectures (above, n. 2), 1:162. On the five parts or offices of the orator, see Cicero, De Inventione I.vii.9, and Quintilian, Institutio Oratoria III.iii.1. See also John Witherspoon, "Lectures on Eloquence" [1800], in Thomas Miller, ed., The Selected Writings of John Witherspoon, ser. Landmarks in rhetoric and public address (Carbondale: Southern Illinois University Press, 1990), 247.

${ }^{30}$ J. Q. Adams, Lectures (above, n. 2), 1:167. 
case of the available means of persuasion." ${ }^{31}$ According to Aristotle, whose doctrine formed the basis for most subsequent classical rhetorical thinking, the available means of persuasion were either artistic or inartistic. Inartistic proof was material drawn from outside the case proper and included proof depending on, for example, laws, contracts, or testimony. Artistic proof, on the other hand, rested on the skill or craft of the speaker in making persuasive arguments and appeals to his audience. Artistic proof consisted of logos, or arguments derived "From the subject of the discourse," ethos, or proof which relied upon the "intellectual and moral qualities of an orator," and pathos, or the "excitation and management of the passions" of the audience. ${ }^{32}$

Several classical rhetoricians developed theoretical systems for assisting the invention of persuasive arguments. In the Aristotelian scheme, the rhetorical topics or commonplaces - forms and lines of argument - were either special (concerned with a specific genre of oratory) or general (applicable to all forms of discourse). For example in persuading the members of a community that war preparations are necessary an orator might rely on arguments based on topics of advantage or expedience (reserved usually for deliberative oratory) and on topics of the possible and impossible or on argument by analogy (both useful in a variety of rhetorical discourses).

With their greater emphasis on forensic oratory, several Roman writers, including Cicero, developed methods of aiding rhetorical invention by investigation of topics or commonplaces associated with the known facts in a case. Roman orators would begin by discovering the issue in a case - the point of stasis - and then pursue questions appropriate to such an issue to reveal the available arguments for the oration. "Thus in

\footnotetext{
${ }^{31}$ Aristotle, Rhetoric 1355 b. 25

${ }^{32}$ J. Q. Adams, Lectures (above, n. 2), 1:343, 367. See Aristotle, Rhetoric 1355b-1356a.
} 
the case of Roscius Amerinus," Adams explained, "Cicero's oration is upon a state of conjecture; whether Roscius committed the deed." In the Pro Milone, however, "it was a state of quality. The fact, that Clodius was killed by Milo or his servants, was undisputed; but Cicero argues, that the act was justifiable self-defence." The state of the controversy, Adams wrote, was "the mark at which all the speaker's discourse aims; the focus, towards which all the rays of his eloquence should converge." ${ }^{33}$ All the topics appropriate for a case are suggested by the point of stasis. Was the dispute one of conjecture? How can the orator establish the probability that the accused did (or did not) commit the act in question? Does the character or manner of the accused make it likely he committed such an act? Has he committed similar or worse acts before? Have his companions committed such acts? From these basic commonplaces an orator might move to others designed to amplify the evil deed. "If I mean to aggravate a crime or injury," John Witherspoon told his Princeton students, "I say it was done deliberately, obstinately, repeatedly, without temptation, against many warnings, and much kindness." The legal advocate could add that the act in question was "very bad to a man's self, to others, to the character, the person, the estate, etc., ${ }^{34}$

In this way, and by considering other proofs available from the orator's character, and those arising from the passions of the audience, the raw material for the oration is discovered. Once the arguments are assembled, however, the orator is then concerned with disposition, "the art of selecting, disposing, and combining them in such order and succession, as shall make them most subservient to [the orator's] design.” Disposition was the "principle of order in rhetoric," said Adams as he followed Cicero's

\footnotetext{
${ }^{33}$ J. Q. Adams, Lectures (above, n. 2), 1:201, 187. See Cicero, De Inventione I.viii.10, and Quintilian, Institutio Oratoria III.vi.1-22.

${ }^{34}$ Witherspoon, "Lectures on Eloquence" (above, n. 29), 280.
} 
recommendation about the parts of an oration. ${ }^{35}$ The classical oratorical form varied slightly from writer to writer, but typically included an exordium, narration, partition, proof, refutation, and peroration. This classical disposition was widely used in American public address in both forensic and deliberative oratory. For example, Webster's famous Reply to Hayne "adheres to the six stages of development set forth in classical oratory." This arrangement, said Robert Ferguson, came as second nature to an orator "who memorized long passages of Cicero's orations." According to Robert Oliver, Charles Sumner also "almost always tried to follow this classic pattern," composing orations that were "vast and elaborately ornamented rhetorical structures, built after classic models.",36 Style, the third office of the orator, concerned "the application of proper words and sentences to the materials of invention." ${ }^{37}$ Clarity, purity, propriety, dignity, sublimity, elegance, ornament, and liveliness were among the virtues of style typically recommended by classical writers and classically minded rhetoricians of the eighteenth and nineteenth centuries. Often classical rhetoric teachers exercised students by inviting them to treat a topic in a variety of styles: the plain, the middle, and the grand. As with other aspects of the discourse, the style of a speech had to fit the character and demands of the speaker, the topic, the occasion, and the genre. To encourage variety and beauty in

\footnotetext{
${ }^{35}$ J. Q. Adams, Lectures (above, n. 2), 1:168, 392. See Cicero, De Inventione I.xiv.19.

${ }^{36}$ Robert A. Ferguson, Law and Letters in American Culture (above, n. 8), 224; Robert T. Oliver, History of Public Speaking in America (Boston: Allyn and Bacon, 1970), 263, 253.

${ }^{37}$ J. Q. Adams, Lectures (above, n. 2), 2:144. In addressing rhetorical style, Adams is governed by the specific mandate of the regulations for the Boylston Chair of Rhetoric and Oratory to "treat generally and largely of elegance, composition, and dignity, and of their respective requisites; and then particularly of the several species of style, as the low, middle, sublime, \&c. and of their distinguishing qualities with respect both to the thoughts and the words, illustrating the same by proper examples" (2:143). He explicitly draws upon "the author of the rhetorics to Herennius" for his discussion of "this combination of elegance, composition, and dignity, as forming the constituent parts of elocution" (2:145). See Rhetorica ad Herennium IV.viii.11 - IV.xi.16. See also Aristotle Rhetoric 1404b ff.
} 
oratorical style, some classical writers offered exhaustive catalogues of the tropes and figures of speech.

There is no doubt that educated Americans in the Golden Age of classical learning sought to imitate Greek and Roman models of oratorical style, especially Cicero. We can hear echoes of the hyperbole, the passionate apostrophe, and the frantic disclosure of the Catilinarian orations in John Hancock's commemorative address on the

\section{Boston Massacre:}

Ye dark designing knaves, ye murderers, parricides! how dare you tread upon the earth which has drank in the blood of slaughtered innocents shed by your wicked hands? How dare you breathe that air which wafted to the ears of heaven the groans of those who fell a sacrifice to your accursed ambition? But if the labouring earth doth not expand her jaws; if the air you breathe is not commissioned to be the minister of death; yet hear it, and tremble! The eye of heaven penetrates the darkest chambers of the soul, traces the leading clue through all the labyrinths which your industrious folly has devised; and you however you may have screen'd yourselves from human eyes, must be arraigned, must lift your hand, red with the blood of those whose death you have procur'd, at the tremendous bar of God! ${ }^{38}$

John Adams, too, read Cicero and other classical writers to develop a "Habit of clear

Thinking and strength and Propriety and Harmony of Expression." ${ }^{39}$ We can recognize

the Ciceronian influence in much of Adams's writing. Consider how the following

passage from his presidential Inaugural Address mimics the vanity, the anaphora, and the

extended periodic style of Cicero's Brutus. Adams told Congress in 1797:

\footnotetext{
${ }^{38}$ Reid, Three Centuries of American Rhetorical Discourse (above, n. 27), 104. Dennis Hannemann maintains that in the late colonial and early national period, public speeches, especially epideictic orations like those commemorating the Boston Massacre, are especially revealing of the depth of classical influence in America. The classical paradigms in such orations contributed significantly to the construction of American national identity as they allowed speaker and reader to make sense of their political circumstances by seeing them in familiar classical terms. See Hannemann, Klassische antike und amerikanische Identitätskonstruktion: Untersuchungen zu Festreden der Revolutionszeit und der frühen Republik, 1770-1815, Beiträge zur englischen und amerikanischen Literatur 27 (Paderborn: Ferdinand Schöningh, 2008). See also Lee T. Pearcy, review of Hannemann, International Journal of the Classical Tradition 16 (2009): 613-616.

${ }^{39}$ Diary and Autobiography of John Adams (above, n. 2), 1:84.
} 
If a resolution to do justice as far as may depend upon me, at all times and to all nations, and maintain peace, friendship and benevolence with all the world; if an unshaken confidence in the honor, spirit, and resources of the American people, on which I have so often hazarded my all and never been deceived; if elevated ideas toward it, founded on a knowledge of the moral principles and intellectual improvements of the people deeply engraven on my mind in early life, and not obscured but exalted by experience and age; and, with humble reverence, I feel it to be my duty to add, if a veneration for the religion of a people who profess and call themselves Christians, and a fixed resolution to consider a decent respect for Christianity among the best recommendations for the public service, can enable me in any degree to comply with your wishes, it shall be my strenuous endeavor that this sagacious injunction of the two Houses shall not be without effect. ${ }^{40}$

In his work on the history of oratory, Cicero boasted to Brutus that no other orator could match his own wisdom and eloquence:

There is not one who has gained more than a common acquaintance with those parts of literature, which feed the springs of Eloquence:- not one who has been thoroughly nurtured at the breast of Philosophy, which is the mother of every excellence either in deed or speech:- not one who has acquired an accurate knowledge of the Civil Law, which is so necessary for the management even of private causes, and to direct the judgment of an Orator:- not one who is a complete master of the Roman History, which would enable us, on many occasions, to appeal to the venerable evidence of the dead:- - not one who can entangle his opponent in such a neat and humourous manner, as to relax the severity of the Judges into a smile or an open laugh: — not one who knows how to dilate and expand, his subject, by reducing it from the limited considerations of time, and person, to some general and indefinite topic; — not one who knows how to enliven it by an agreeable digression: not one who can rouse the indignation of the Judge, or extort from him the tear of compassion;- - or who can influence and bend his soul (which is confessedly the capital perfection of an Orator) in such a manner as shall best suit his purpose. ${ }^{41}$

Note here how both the Adams excerpt and the Cicero passage offer extended selfportraits that affirm the virtues of the writer, even as they enact one of those virtues in an effort at eloquent expression. Both Adams and Cicero use the structure of a long periodic sentence to focus attention on the particular characteristics that qualify them to be

\footnotetext{
${ }^{40}$ John Adams, Works (above, n. 11), 9:110.

${ }^{41}$ E. Jones, trans., Cicero's Brutus, or History of Famous Orators. Also his Orator, or Accomplished Speaker (London: R. White, 1776), 225-227.
} 
considered as worthy of the dignity each claims. The resolution of each sentence is delayed and the tension sustained by the accumulation of clauses, each of which contributes another dimension to the personal portrait of the writer. And, that accumulation of clauses is emphasized by the figure of anaphora, as the introduction of each clause is signaled by the repetition of an opening phrase. Each passage, then, uses rhetorical form and style to reinforce the very point advanced by the author. As the sentence in each excerpt is long, so has been the career of Adams in service to his country, and that of Cicero in the development of his oratorical skills and reputation.

Not every Founding Father who studied the classics, however, preferred the Ciceronian style of oratory. In 1810, Thomas Jefferson complained that members of Congress had gotten too long-winded. "These speeches, therefore, are less and less read," he told J. W. Eppes. "The models for that oratory which is to produce the greatest effect by securing the attention of hearers and readers, are to be found in Livy, Tacitus, Sallust, and most assuredly not in Cicero."42

Once the speech had been crafted in appropriate language it had to be remembered. Therefore the classical rhetoricians encouraged the development of memory, the fourth office of the orator. "Memory," thought John Quincy Adams, is "peculiarly connected with rhetoric." Not only must an orator depend on recalling an idea at the proper moment, but also "the expression with which it is clothed." If the memory fails, and "at the precise point of time, when they are needed, the thought or its

\footnotetext{
${ }^{42}$ Thomas Jefferson to J. W. Eppes, 17 January 1810, in Andrew Lipscombe, ed., The Writings of Thomas Jefferson, Vol. 12 (Washington: Thomas Jefferson Memorial Association, 1903), 343, cited in Louis B. Wright, "Thomas Jefferson and the Classics," Proceedings of the American Philosophical Society 87 (1943): 228.
} 
vehicle refuse their office, the opportunity is lost, never to be retrieved."43 While today speakers may employ electronic teleprompters, in the Golden Age of American oratory memory was still a vital and much cultivated art. Daniel Webster, for example, delivered his memorable Reply to Hayne from a single page of notes, while Charles Sumner delivered his famous six-hour oration, "The Crime Against Kansas," entirely from memory. ${ }^{44}$

The last office of the orator is delivery. Citing Cicero's De Oratore John Quincy Adams recalled for his students that "well known anecdote" about Demosthenes who, when asked which art was most important to an orator, answered "delivery." When asked what was the second and third, he again answered "delivery," "delivery."45 As with the other parts of the art of rhetoric, American orators turned to classical sources for instruction on delivery. The "most complete and most methodical" treatment of delivery, John Quincy Adams thought, was to be found in Quintilian whose "principal rules of oratorical action ... may still be studied to advantage, and applied with success."46 No less than the other aspects of the art, American orators polished their skills in delivery, for failure in this last office, notwithstanding the brilliant sentiment of the written oration, might bring dishonor and obscurity. As Chauncey Goodrich told students at Yale, "to infuse into the delivery all the force of which the sentence is capable, requires study, and experiment with various modes till the best is discovered." He reminded them "the great

\footnotetext{
${ }^{43}$ J. Q. Adams, Lectures (above, n. 2), 2:359-360. See Quintilian, Institutio Oratoria XI.ii.1-51.

${ }^{44}$ Robert T. Oliver, History of Public Speaking in America (above, n. 36), 150n, 265.

${ }^{45}$ J. Q. Adams, Lectures (above, n. 2), 2:374. See Cicero, De Oratore III.lvi.213. The anecdote about Demosthenes was indeed well known. See John Ward, A System of Oratory, Delivered in a Course of Lectures Publicly Read at Gresham College, 2 Vols. (London: John Ward, 1759), 2:314; Wirt, Sketches of the Life and Character of Patrick Henry (above, n. 1), 91; John Adams to William Wirt, 23 January, 1818, in Works (above, n. 11), 10:279; D. A. Harsha, The Life of Charles Sumner: with Choice Specimens of his Eloquence, A Delineation of his Oratorical Character, and His Great Speech on Kansas (New York: Dayton, 1860), 152.

${ }^{46}$ J. Q. Adams, Lectures (above, n. 2), 2:385, 391. See Quintilian, Institutio Oratoria XI.iii.1-184.
} 
Orators of Antiquity scarcely ever trusted themselves to speak in public until they had composed their productions with unwearied labor, and prepared for their delivery by numerous repetitions. ${ }^{, 47}$ Indeed, many American orators achieved renown, in part, for their passionate delivery. Patrick Henry's voice "had a wonderful effect. He had a singular power of infusing it into a jury, and mixing its notes with their nerves, in a manner which it is impossible to describe justly; but which produced a thrilling excitement, in the happiest concordance with his designs. ${ }^{\circ 8}$ One biographer of Fisher Ames described the posture of the Massachusetts orator as "erect and easy, his gestures manly and forcible, his intonations varied and expressive, his articulation distinct, and his whole manner animated and natural." ${ }^{49}$ Charles Sumner had "a singularly sweet and melodious voice, whose tones are perfectly suited to descriptive, pathetic, indignant and impassioned declamation," which was complemented by his "graceful, animated and often vehement" gestures. ${ }^{50}$

The lectures by John Quincy Adams, along with the lessons of other American rhetoricians used here to assist in the review of classical rhetorical theory begin to suggest the status of classical rhetoric in American culture of the colonial and early national period. Not only at Harvard but in nearly all American colleges and academies, not only in lectures but in the reading of classical and modern textbooks, students were thoroughly indoctrinated and drilled in the classical rhetorical tradition. Moreover, the rhetorical theories advanced by Aristotle, Cicero, and Quintilian informed the practice of

\footnotetext{
${ }^{47}$ John P. Hoshor, ed., "Lectures on Rhetoric and Public Speaking By Chauncy Allen Goodrich," Speech Monographs 14 (1947): 28.

${ }^{48}$ Wirt, Sketches of the Life and Character of Patrick Henry (above, n. 1), 73.

${ }^{49}$ [J. T. Kirkland] "Notices of the Life and Character of Fisher Ames," in Works of Fisher Ames (Boston: T. B. Wait \& Co., 1809), xxi.

${ }^{50}$ Harsha, The Life of Charles Sumner (above, n. 46) 153.
} 
American rhetoric in every phase of public discourse and debate, at every level of popular ceremony, law, and deliberation.

\section{Classical Rhetoric and Oratory in the Academy}

To gain admission to most early American colleges, prospective students had to show they were able to render "Tully's orations into English," or translate "Cicero's Select Orations," or "read accurately construe and parse Tully," or demonstrate "a good acquaintance with ... Cicero's Select Orations." ${ }^{\text {51 }}$ Such admission requirements meant that in the preparatory schools and Latin academies nearly all pupils were reading Cicero to prepare for entrance to the college of their choice.

Once these students had gained admission their instruction in classical rhetoric and Latin and Greek oratory was only beginning. "We study the ancient orators," explained Edward T. Channing in his lectures at Harvard, "not merely as useful in rhetorical instruction, but also as occupying an important place in literature, affording examples of great and finished men in active and political life." ${ }^{, 52}$ At some colleges, students reviewed Cicero's orations in the first year; others kept the orations in the curriculum into the senior year.

\footnotetext{
${ }^{51}$ Thomas Jefferson Wertenbaker, Princeton, 1746-1896 (Princeton: Princeton University Press, 1946), 91; Brooks Mather Kelley, Yale, A History (New Haven: Yale University Press, 1974), 156; Walter C. Bronson, The History of Brown University, 1764-1914 (New York: Arno Press, 1971), 102; Baxter Perry Smith, The History of Dartmouth College (Boston: Houghton Osgood, \& Co., 1878), 83-84. One popular preparatory text was M. Tullii Ciceronis Orationum Selectarum Liber editus in usum scholarum Hollandiae \& West-Frisiae (London: J. Walthoe, et al., 1734).

${ }^{52}$ Edward T. Channing, Lectures Read to the Seniors in Harvard College, Dorothy I. Anderson and Waldo Braden, eds. (Boston: Ticknor \& Fields, 1856; rpt. Carbondale: Southern Illinois University Press, 1968), 10. The study of classical rhetoric and oratory was part of a more comprehensive classical curriculum. See William J. Ziobro, "Classical Education in Colonial America," in Meckler, ed. Classical Antiquity and the Politics of America" (above, n. 5), 13-28.
} 
As an orator and patriot, Cicero was widely admired by American college students. "Did not his eloquence drive the wretches of Cataline's [sic] conspiracy from the City, like chaff before the wind?" one student asked. "And what greater proof could we have of its energetic influence, than to see the war-like, the despotic Caesar grow pale and tremble at his pleading?",53

In addition, to learn Greek and "to study oratory," students were often required to read the orations of Demosthenes. ${ }^{54}$ As a graduating student told the commencement crowd at the College of Rhode Island (Brown University) in 1769, Demosthenes was "the Oracal [sic] of Greece; that prince of Orators." 55 Often students read "On the Crown," but they seemed to admire most the heroic "Philippics" wherein Demosthenes "with a soul superior to corruption, and an eloquence irresistible asserted the cause of freedom, and roused his countrymen from their languor and stupidity to a firm and spirited resistance." ${ }^{56}$ It was not unusual, then, to find that graduating students had spent hours reading "the burning pages of Demosthenes: or the more luxuriant decorations of Tully."57

Most professors of rhetoric and oratory assumed a familiarity with the classical orations as they instructed students in the art of public speaking. John Witherspoon, for example, who lectured on eloquence at Princeton, consistently turned to Cicero as both a theoretical authority and a paradigm of eloquence. "There are some fine examples of address and delicacy in Cicero," he told his students, "particularly in his orations pro

\footnotetext{
${ }^{53}$ Child, "An Oration on Eloquence” (above, n. 4), 20.

${ }^{54}$ David C. Humphrey, From King's College to Columbia, 1746-1800 (New York: Columbia University Press, 1976), 177.

${ }^{55}$ Bronson, The History of Brown University (above, n. 51), 123.

${ }^{56}$ Child, "An Oration on Eloquence" (above, n. 4), 8.

${ }^{57}$ Francis Walker Gilmer, Sketches of American Orators (Baltimore: Fielding Lucas, 1816), 45.
} 
Roscio, pro Milone, et de lege argraria." ${ }^{58}$ For Chauncey Allen Goodrich at Yale, the principal model was Demosthenes. Reading the orations of that Athenian master, he said, "you feel yourself to be embarked on a mighty stream. Every thing is bearing you towards one great result; all is involved with deep feeling.,"59

Side by side with Roman and Athenian oratory, American college students read the classical theoretical treatises on rhetoric. Some colleges included Quintilian or Longinus among their required readings, but almost without exception the central theoretical text on rhetoric was Cicero's De Oratore. The work was commonly available in libraries and bookshops in both Latin and English, and was so central to the college curriculum that it is not an exaggeration to say that nearly every educated American during the first fifty years of the republic had read De Oratore. Studied at Harvard, Dartmouth, Brown, Yale, Columbia, Williams, Georgetown and nearly every other American college, De Oratore was not only the most widely read text on rhetoric, but also part of the common intellectual currency of the early republic. In reading $D e$ Oratore, John Quincy Adams told his students, each "future orator" must "consume the last drop of his midnight oil, and hail the first beam of returning dawn." For orators, said Adams, "Cicero is the friend of the soul, whom we can never meet without a gleam of pleasure; from whom we can never part, but with reluctance." 60

\footnotetext{
${ }^{58}$ Witherspoon, "Lectures on Eloquence" (above, n. 29) 303.

${ }^{59}$ Goodrich, "Lectures on Rhetoric and Public Speaking" (above, n. 47), 7.

${ }^{60} \mathrm{~J}$. Q. Adams, Lectures (above, n. 2),1:100, 115. If we are to judge by the published lectures of the period, the program of rhetorical instruction in American colleges was generally similar to that undertaken at British universities, except that the transition to an emphasis upon written composition and belles lettres, typical in Scottish universities in the eighteenth-century, happens considerably later in America. For the most part, during the eighteenth and early nineteenth centuries, American instruction tended to follow the model advanced by British Ciceronians like John Ward. And, the classical influence persisted longer in the United States, even in combination with the new rhetoric of the Scottish Enlightenment, than in Great Britain. See Wilbur Samuel Howell, Eighteenth-Century British Logic and Rhetoric (Princeton: Princeton University Press, 1971), especially his chapter on "The Eighteenth-Century Ciceronians" 75-141.
} 
But not all reading in rhetoric originated from the classical period. Professors of rhetoric were often eager to incorporate modern works on the art into their curriculum. Even then, however, the eighteenth-century works imported from Edinburgh or London for use in American colleges presented a complete classical doctrine or at least relied heavily on classical theory and examples. The most popular of such texts were John Ward's System of Oratory, and Hugh Blair's Lectures on Rhetoric and Belles Lettres.

Published in 1759, Ward's work is clearly within the classical tradition. His lectures were the model for the Boylston Professorship at Harvard and were used regularly in the curriculum of Brown University. ${ }^{61}$ Ward depends entirely upon the classical writers for both his theoretical doctrines and his examples of the art in practice. "The method of forming the best system of oratory," he wrote, "is to collect it from the finest precepts of Aristotle, Cicero, Quintilian, Longinus, and other celebrated authors; with proper examples taken from the choicest parts of the purest antiquity."

Hugh Blair's Lectures on Rhetoric and Belles Lettres (1783) was widely used in American college classrooms until at least the middle of the nineteenth century, sometimes replacing classical works like De Oratore, more often read alongside Cicero, Quintilian, and the classical orations. ${ }^{63}$ Although Blair proposed some significant amendments in classical rhetorical theory, he never entirely abandoned the ancient rhetoricians or orators. Cicero's theoretical works, especially De Oratore, he thought

\footnotetext{
${ }^{61}$ Ron F. Reid, "The Boylston Professorship of Rhetoric and Oratory, 1806-1904: A Case Study in Changing Concepts of Rhetoric and Pedagogy," Quarterly Journal of Speech 45 (1959): 241; Reid, "John Ward's Influence in America: Joseph McKean and the Boylston Lectures on Rhetoric and Oratory," Speech Monographs 27 (1960): 340-344; Kenneth Frandsen, "Ward, Adams, and Classical Rhetoric," Southern Speech Journal 34 (1968): 108-115; Bronson, The History of Brown University (above, n. 51), 102.

${ }^{62}$ Ward, A System of Oratory (above, n. 45), 1:15. Ward relies heavily on Cicero's orations, especially the Pro Milone, as examples of theoretical principles in practice.

${ }^{63}$ At Williams College, for example, both Blair and Cicero were used as late as 1855 when De Oratore was finally dropped from the curriculum.
} 
useful and "worthy of attention," but "of all the Ancient Writers on the subject of Oratory," Quintilian was "the most instructive and most useful." Blair told his readers not to omit "to read any part of [Quintilian's] Institutions."64 Classical orations, too, remained the principal models of eloquence recommended by Blair. He included long excerpts from both Cicero, "whose name alone suggests every thing that is splendid in Oratory," and Demosthenes, "in whom, it must be acknowledged, Eloquence shone forth with higher splendor, than perhaps in any that ever bore the name of an orator." ${ }^{, 65}$

Several other works on rhetoric available in America in the eighteenth and early nineteenth century deserve mention for the strong classical lines they exhibit. Charles Rollin's The Method of Teaching and Studying the Belles Lettres, as the author admitted, was "for the most part borrowed from Cicero and Quintilian," and recommended Cicero and Demosthenes as the most perfect models of eloquence as judged by "the consent of all ages and of all the learned." 66 John Lawson's Lectures Concerning Oratory (1758) was also firmly in the classical tradition, and although not as widely read as Ward, Blair, or Rollin, was available to students at Harvard, Brown, and Yale. ${ }^{67}$ Other minor treatments of rhetoric with a classical flavor which achieved respectable circulation in

\footnotetext{
${ }^{64}$ Hugh Blair, Lectures on Rhetoric and Belles Lettres, 2 vols., ed. Harold F. Harding (Carbondale: Southern Illinois University Press, 1965), 2:244-45.

${ }^{65}$ Blair, Lectures, 2:26, 19.

${ }^{66}$ Charles Rollin, The Method of Teaching and Studying the Belles Lettres, $10^{\text {th }}$ edition, 4 vols. (Edinburgh: Drummond, Donaldson, Bell and Elliot, 1773), 2:194. Rollin's work was translated from the original French and widely circulated in the American colonies. John Adams thought the volumes of Rollin's treatise "worth their weight in gold" (see Adams, Earliest Diary, 52). See also John Adams to Abigail Adams, 7 July 1776, in L. H. Butterfield, ed., Adams Family Correspondence (New York: Atheneum, 1965), 2:39-40.

${ }^{67}$ E. Neal Claussen and Karl R. Wallace, "Editor's Introduction," in Lawson, Lectures Concerning Oratory (above, n. 2), xliv.
} 
America included John Holmes's Art of Rhetoric Made Easy, John Brightland's

Grammar, Robert Dodsley's Preceptor, and James Burgh's The Art of Speaking. ${ }^{68}$

\section{Classical Rhetoric in Popular American Journals}

We find the pursuit of classical rhetoric, so vital to the college curriculum of early America, also taken up in the periodical literature of the late eighteenth and early nineteenth centuries. As with the major treatises on the subject, numerous articles published in the literary and popular journals of the time treat rhetoric and oratory as classical arts, and often recommend Cicero and Demosthenes as distinguished models of ancient eloquence. In fact, the titles alone display a hint of the wide interest in classical rhetoric and oratory: "Ancient Eloquence," "Demosthenes," "The Roman Orators," Popular Eloquence of the Romans," "Ancient and Modern Eloquence," "Athenian Orators," "Eloquence of the Romans."69 Some essays on rhetoric were merely abridgments or condensations of the published lectures by Blair or some other writer. Other pieces were original if not less classical. One particularly thoughtful treatment of eloquence laid out a nearly complete system of classical rhetoric over several volumes of the Christian Scholar's and Farmer's Magazine. The anonymous author relied heavily on Quintilian and wrote of oratory as "the art of which Demosthenes, Aristotle,

\footnotetext{
${ }^{68}$ John Holmes, The Art of Rhetoric Made Easy (London: C. Hitch and L. Hawes, 1755); John Brightland, A Grammar of the English Tongue, with the Arts of Logick, Rhetorick, Poetry, \&c Illustrated with Useful Notes, Giving the Grounds and Reasons of Grammar in General (London: James Rivington and James Fletcher, 1759); Robert Dodsley, The Preceptor: Containing a General Course of Education, Wherein the First Principles of Polite Learning are Laid Down In a Way most suitable for trying the Genius, and advancing the Instruction of Youth, 2 vols. (London: R. and J. Dodsley, 1758); James Burgh, The Art of Speaking, $4^{\text {th }}$ edition (Philadelphia, R. Aitken, 1775).

69 “Ancient Eloquence," Southern Literary Messenger 6 (1840): 166; "Demosthenes," The North American Review 22 (1826): 51; “The Roman Orators," Southern Review 2 (1828): 492; "Popular Eloquence of the Romans," North American Review 30 (1830): 273; “Ancient and Modern Eloquence," Eclectic Magazine 23 (1856): 17; “Athenian Orators," Southern Quarterly Review 20 (1851): 352; J. L. Kingsley, "Eloquence of the Romans," North American Review 30 (1829): 259.
} 
Quintilian, Cicero ... have been the masters and models."70 Another author remarked that no "better foundation can be laid for proficiency in popular eloquence, than in the study of what has descended to us from antiquity."71 The attention given to classical rhetoric in popular American magazines suggests, as Stephen Chambers and G. P. Mohrmann have argued, that well into the nineteenth century "classical theory exhibits a vigor well beyond its generally accepted decline in the schools."

As they were in the textbooks and classrooms of the period, Demosthenes and Cicero were the eloquent heroes of ancient times most often recommended by the periodical authors, critics and editors. The Massachusetts Magazine published "A Comparison between Demosthenes and Cicero," the two "greatest orators the world ever produced," whose orations are "still esteemed as the genuine works of nature, as the most excellent models of eloquence and as the most surprising exertions of human genius and learning."73 In another publication, a series of dialogues between "Demosthenes" and "Cicero" set out to determine the "character of true eloquence," and the "difference between an orator and a real philosopher." ${ }^{, 74}$ The constant turn to these classical models

\footnotetext{
70 "An Analytical Abridgment of the Principal of the Polite Arts, Belles Lettres, \& Science; particularly Grammar, Rhetoric, Eloquence, etc.," The Christian Scholar's and Farmer's Magazine (April-May 1789): 56-61.

71 "Popular Eloquence of the Romans," North American Review 30 (1830): 273, cited in Stephen Chambers and G. P. Mohrmann, "Rhetoric in Some American Periodicals, 1815-1850," Speech Monographs 37 (1970): 119. See also James M. Farrell and Joseph M. Noone, "Rhetoric, Eloquence, and Oratory in Eighteenth-Century American Periodicals: An Annotated Bibliography," Rhetoric Society Quarterly 23, No. 2 (1993): 72-80.

${ }^{72}$ Chambers and Morhrmann, "Rhetoric in Some American Periodicals," 120.

73 "Comparison between Demosthenes and Cicero," Massachusetts Magazine 6 (1794): 531-32. The comparison appears to draw from a number of sources including Plutarch, Longinus, and Fénelon. See: John Langhorne and William Langhorne, Plutarch's Lives, translated from the original Greek, with notes critical and historical, Vol. 5 (London: Edward \& Charles Dilly, 1770), 327-331; Dionysius Longinus, On the Sublime, translated from the Greek with Notes and Observations, trans. William Smith (London: B. Dod, 1743), 36-37; François de Salignac de La Mothe- Fénelon, Dialogues Concerning Eloquence in General: and Particularly that Kind which is fit for the Pulpit, trans. William Stevenson (London: J. Walthoe, 1722), 236-37.

74 “A Dialogue between Demosthenes and Cicero," Christian Scholar's and Farmer's Magazine (AprilMay, 1789): 61, continued June-July 1789, 271. This item is a translation from Fénelon's Dialogues des
} 
certainly helped popularize the heroic eloquence of Demosthenes and Cicero and spread their fame and influence beyond the academy. But such popular treatments of ancient orators also encouraged continued comparison between developing American eloquence and the much esteemed rhetorical expression of the classical period. One anonymous critic believed that "we are living over again the classic times of Athenian and Roman eloquence, on a broader stage, in larger proportions, with elements of excitement, hopes of progress, and principles of duration, which never cheered and strengthened the souls of Demosthenes and Cicero."75

\section{Classical Parallels in American Public Address}

Both classical models of oratory and classical rhetorical theory influenced American rhetorical practice during the colonial and early national periods. As George Kennedy has observed, "antiquity supplied forms of thought, argument, expression, and composition which were the bases of educated communication and persuasion in the civilized world," during that age. ${ }^{76}$ We can clearly mark the influence of the classical world in eighteenth- and nineteenth-century American public address because, as Caroline Winterer explains, "after 1750, oratory flourished as an essential element of civic life in America," and "the benefits of a classical education were especially obvious

\footnotetext{
Morts. See François de Salignac de La Mothe Fénelon, Dialogues of the Dead; Together with Some Fables, composed for the Education of a Prince, trans. Mr. Elphingston, Vol. 1 (Glasgow: Robert and Andrew Foulis, 1754), 162-171.

75 “Everett's Orations and Speeches," North American Review 71 (1850): 445-46, cited in Chambers and Mohrmann, "Rhetoric in Some American Periodicals" (above, n. 71), 114.

${ }^{76}$ George Kennedy, "Classical Influences on The Federalist," in John F. Eadie, ed., Classical Traditions in Early America (Ann Arbor: Center for Coordination of Ancient and Modern Studies, University of Michigan, 1976), 119. See also Harry Caplan, "The Classical Tradition: Rhetoric and Oratory," Rhetoric Society Quarterly 27 (1997): 1-33, esp. 29.
} 
in oratory."77 American orators followed classical rhetorical theories of invention, disposition, style and delivery (see above, pp. 10-12). Pamphleteers often used classical pseudonyms, quoted from classical writers, and drew explicit analogies between modern and ancient events. The epics, histories, philosophies, orations, letters, and lives of ancient Greece and Rome provided the public men of America not only with classical tag lines to adorn their essays and speeches, but with personal models of eloquence and civic conduct. In 1758, a young John Adams recorded in his diary that he spent the day and evening reading aloud Cicero's four orations against Catiline. “The Sweetness and Grandeur of his sounds, and the Harmony of his Numbers give Pleasure enough to reward the Reading if one understood none of his meaning," Adams wrote. "Besides, I find it a noble Exercise. It exercises my Lungs, raises my Spirits, opens my Porrs, [sic] quickens the Circulations, and so contributes much to Health."78 As a student at Columbia in the 1780s John Randolph "used to cry for indignation at the success of Phillip's arts and arms over the liberties of Greece" as he and his tutor "read Demosthenes together.",79

Given the widespread study of ancient paradigms of eloquence, it is not surprising to find loud echoes of the classical voice in American discourse. American orators often set out the eloquent heroes of the classical period as worthy of praise and emulation. In reflecting on "the eloquence of Revolutionary periods," Rufus Choate turned the attention of his audience to ancient Athens and "the first name in all eloquence - Demosthenes." The great Greek orator, "the most Athenian of Athenians, the most Greek of all the

\footnotetext{
${ }^{77}$ Caroline Winterer, The Culture of Classicism: Greece and Rome in American Intellectual Life, 17801910 (Baltimore: The Johns Hopkins University Press, 2002), 25, 20.

${ }^{78}$ John Adams, Diary and Autobiography (above, n. 19), 1:63.

${ }^{79}$ Robert Dawidoff, The Education of John Randolph (New York: W. W. Norton, 1979), 117.
} 
Greeks," uttered "the last and noblest protest of Grecian independence," and poured out "passionate patriotism of the freest and most country-loving of all the races of man, in one final strain of higher mood than the world before or since has heard." ${ }^{\prime 80}$ Edward Everett also praised Demosthenes, and Cicero from whose lips "the soul of republican liberty did burst forth," producing in him "the best specimens of a purely original literature, which the Romans have transmitted to us." ${ }^{.81}$

The influence of the classics was felt in numerous ways, but perhaps with no more force than when orators and writers employed extended classical analogies to illuminate and color contemporary political disputes. In his commemorative oration on the Boston Massacre, Joseph Warren traced the parallels between the decline of Rome and the corruption of British civilization. "It was this noble attachment to a free constitution," he proclaimed, "which raised ancient Rome, from the smallest beginnings, to that bright summit of happiness and glory to which she arrived; and it was the loss of this which plunged her from that summit into the black gulph [sic] of infamy and slavery." $" 82$

While most often it was England that had to bear comparison to ancient Rome, some Federalist writers turned the ancient lamp toward France. Fisher Ames, for example, who had "contemplated the character of Cicero as an orator and statesman with fervent admiration," raved against the French Revolution in a series of political essays

\footnotetext{
${ }^{80}$ Rufus Choate, Addresses and Orations (above, n. 8), 175.

${ }^{81}$ Edward Everett, "The Circumstances Favorable to the Progress of Literature in America," Orations and Speeches on Various Occasions (above, n. 28), 1:25. See also "Education of Mankind," Orations and Speeches on Various Occasions, 1:424-425.

${ }^{82}$ Joseph Warren, "Oration Delivered at Boston, March 5, 1772," in Hezekiah Niles, Principles and acts of the revolution in America: or, An attempt to collect and preserve some of the speeches, orations, \& proceedings, with sketches and remarks on men and things, and other fugitive or neglected pieces, belonging to the revolutionary period in the United States (Baltimore: William Ogden Niles, 1822), 4-5. See also Hanneman, Klassische antike und amerikanische Identitätskonstruktion (above, n. 38) 190-213.
} 
entitled "The New Romans." Ames warned that the rising militarism and intolerance of the French was reminiscent of the arrogance and martial spirit of the Roman Empire. "Since the Romans," Ames wrote, "no nation has appeared on the stage of human affairs, with a character completely military, except the French." He went on to propose that "Like Rome, who extended her conquests, while she was convulsed with civil war, every change has breathed new fury into the military enthusiasm of France." ${ }^{.83}$

Such analogies were instructive, not merely ornamental. The classical parallels act as metaphors, providing color and depth to a contemporary event, allowing the orator to clearly articulate his view in a language shared and revered by his audience. Take for example Charles Sumner's famous 1856 oration "The Crime Against Kansas." Calling to mind dramatic scenes from Cicero's career, Sumner drew an extended parallel between his attack on the slave power and "the terrible impeachment by which the great Roman orator has blasted through all time, the name of Verres." And yet, said Sumner, even "the wrongs of much abused Sicily, thus memorable in history, were small by the side of the wrongs of Kansas.” Later in the speech Sumner attacked David R. Rice, pro-slavery Senator from Missouri. "Like Catiline," Sumner proposed, "he stalked into this Chamber, reeking with conspiracy - immo in Senatum venit - and then like Catiline he skulked away - abiit, excessit, evasit, erupit - to join and provoke the conspirators, who at a distance awaited their congenial chief." What was worse, "the similitude with Catiline was again renewed in the sympathy, not even concealed, which he found in the very Senate itself, where, beyond even the Roman example, a Senator has not hesitated to appear as his open compurgator." Sumner lamented that despite the strong evidence of a slave power conspiracy, "Nonnulli sunt in hoc ordine, qui aut ea, quae imminent, non

\footnotetext{
${ }^{83}$ Fisher Ames, Works (above, n. 49), xxiii, 188, 190.
} 
videant; aut ea, quae vident, dissimulent; qui spem Catilinae mollibus sententiis aluerunt, conjurationemque nascentem non credendo corroboraverunt. ${ }^{, 84}$ To an audience nurtured on the orations of Cicero, the analogy suggested the central rhetorical challenge the speaker had taken up. The villainy of the slave power is cast in mythic terms by comparison with two infamous scoundrels of the classical period, known to nineteenthcentury listeners and readers through their shared classical education in rhetoric and oratory. Moreover, by such comparison, the speaker himself attains for his own character a potent, even heroic ethos. If the parallels resonate with the listening audience the speaker depicts himself as the pater patriae in an eloquent struggle to save his native land.

Sumner likely hoped his efforts in eloquently opposing such nefarious threats would gain him a measure of fame as a notable American orator. After all, it was in addressing the great political questions of their time that Demosthenes and Cicero secured a lasting reputation as eloquent heroes. "The fire with which they consumed Philip, and Catiline, and Verres, and Antony," wrote Francis Walker Gilmer, "has covered them with unfading glory." 85 The classical value system that glorified the achievements of Demosthenes and Cicero also animated many of America's great orators in their quest for historical immortality. Eloquence in service to the country was one sure

\footnotetext{
${ }^{84}$ Charles Sumner, "The Crime Against Kansas. The Apologies for the Crime. The True Remedy," in Recent Speeches and Addresses by Charles Sumner (Boston: Higgins, Bradley and Dayton, 1857), 589-90, 611-12, 628. The passage is from Cicero's "First Oration Against Catiline" (I.xii.30): "But there are some of this very order, who do not either see the dangers which hang over us, or else dissemble what they see; who, by the softness of their votes, cherish Catiline's hopes, and add strength to the conspiracy by not believing it," in Cicero's Select Orations, trans. William Duncan (New Haven: Sidney's Press, 1811): 135. Gilbert Highet notes that when Edmund Burke impeached Warren Hastings, he too "modelled his attack on Cicero's successful prosecution of Verres ... and the whole court knew it," The Classical Tradition: Greek and Roman Influences on Western Literature (New York: Oxford University Press, 1976), 328. Sumner no doubt knew Burke's speeches against Hastings well.

${ }^{85}$ Gilmer, Sketches of American Orators (above, n. 57), 40.
} 
road, many thought, to lasting fame and remembrance. Indeed, we remember Adams, Otis, Henry, Ames, Webster, Clay, and Sumner, in part, because they spoke with wisdom and passion in times of the greatest national importance on "subjects demanding the highest decorations of eloquence." 86 Their great orations compose the record of our most vital national debates. Along with Sumner's speeches, those of the other great orators would be remembered "like the imperishable orations of Demosthenes, Cicero, Chatham, and Burke," and "studied and admired by posterity.",87

\section{Conclusion}

Some American orators met the great moments of national crisis with eloquence worthy of fame. Yet the rising fame of American orators signaled the waning influence of classical models and accompanied the decline of classical rhetoric in the American academy. As the country developed her own rhetorical legacy the speeches of Fisher Ames, Edward Everett, and Daniel Webster replaced the well-known orations of Cicero and Demosthenes in the schoolbooks and oratorical anthologies of the later nineteenth century. As Barnet Baskerville notes, the "comparison of ancient and modern eloquence gave way after the Civil War to a concern for the decline of modern oratory. It was no longer a matter of whether Webster and Clay were superior to Demosthenes and Cicero, but whether there was anyone in postwar America to compare with Webster and Clay." ${ }^{\text {" }}$ At the same time, the academic study of rhetoric became separated from the pursuit of

\footnotetext{
${ }^{86}$ Gilmer, Sketches of American Orators (above, n. 57), 39.

${ }^{87}$ Harsha, The Life of Charles Sumner (above, n. 45), 111. On the importance of classical models as an inspiration to oratorical fame, see James M. Farrell, “John Adams's Autobiography: The Ciceronian Paradigm and the Quest for Fame," New England Quarterly 62 (1989): 505-528.

${ }^{88}$ Baskerville, "Principal Themes of Nineteenth-Century Critics of Oratory," Speech Monographs 19 (1952), 25.
} 
classical literature and lodged in emerging departments of English. As a result, the immediate, civic, and argumentative nature of spoken oratory gave way to theories of rhetoric that emphasized literary style and written composition. Elocution studies, the remnant of the old rhetorical curriculum, retained little that was recognizable from its classical heritage.

Nevertheless, the influence of classical rhetoric and oratory on the public discourse of colonial and early republican America was undeniably profound. Perhaps no other aspect of American culture bears the mark of the classical tradition as prominently as that of rhetoric and oratory. What Gilbert Highet said of the impact of the classics on British oratory might also apply to the history of American eloquence. "The best orations of Burke, and Pitt, and Fox, and Sheridan are Ciceronian in almost everything but language," he explained. "The high standard set by these men, and many of the Latin devices they naturalized, have survived to our own time, to influence many modern speakers who know nothing of Latin and have no idea that they are pupils of Cicero." ${ }^{89}$ Whether or not there are traces of Cicero or Demosthenes in modern American political discourse it is certainly true that for nearly a century American rhetoric, in theory and practice, was thoroughly classical. In molding our character as a nation, in determining the national course, in articulating the form and style of America's civil religion, the eloquent heroes of American history relied heavily on the instruction and models from ancient times. Today we cannot read a speech from that age and fail to recognize the doctrines of Aristotle, Cicero, or Quintilian. Nor can we read the history of our famous legal trials or our great national debates without hearing echoes from the Athenian assembly or the Roman forum.

\footnotetext{
${ }^{89}$ Highet, The Classical Tradition (above, n. 84), 397.
} 